\title{
Short Communication ANTICLASTOGENIC EFFECT OF VITAMIN C ON CISPLATIN in vivo
}

\author{
Lusânia M. Greggi Antunes, Joana D.C. Darin and Maria de Lourdes P. Bianchi
}

\begin{abstract}
The ability of vitamin $C(\mathrm{VC})$ to protect against the clastogenic action of the chemotherapeutic agent cisplatin (DDP, cis-diamminedichloroplatinun II) in rat bone marrow cells was evaluated. DDP was administered to Wistar rats either alone or after treatment with VC. The rats were treated with VC $(50,100$ or $200 \mathrm{mg} / \mathrm{kg}$ body weight) by gavage $10 \mathrm{~min}$ before the administration of DDP ( $5 \mathrm{mg} / \mathrm{kg}$ body weight, ip) and then sacrificed $24 \mathrm{~h}$ after treatment. VC significantly reduced (by about $70 \%$ ) the clastogenicity of DDP in rat bone marrow cells. The antioxidant action of VC presumably modulates the clastogenic action of DDP.
\end{abstract}

\section{INTRODUCTION}

Free radical-mediated reactions are responsible for a wide range of chemotherapy-induced side effects, and antioxidants are able to protect non-malignant cells and organs against damage by cytostatic agents (Weijl et al., 1997). In animals, the administration of antioxidants does not compromise the antitumor effect of chemotherapeutic drugs such as doxorubicin and bleomycin (Keizer et al., 1990; Weijl et al., 1997). Cisplatin (DDP, cis-diamminedichloroplatinum II), one of the most potent antitumor drugs, is active against a variety of neoplasms. The antitumor action of DDP is atributted to its action on DNA synthesis (Crul et al., 1997). However, the use of DDP is limited because of its toxicity to normal tissues (Rosenberg, 1985). DDP is highty mutagenic, causing sister-chromatid exchange and chromosomal aberrations in cultured mammalian cells, mouse bone marrow cells, and peripheral blood lymphocytes of patients (Kliesch and Adler, 1987; Adler and El-Tarras, 1989; Ohe et al., 1990; Osanto et al., 1991; Krishnaswamy and Dewey, 1993). The generation of free radicals is believed to be an important mechanism in the development of DDP toxicity (Masuda et al., 1994; Baliga et al., 1998).

Much attention has been given to the possible role that antioxidants play in protecting against DDP-induced toxicity in mammalian systems (Baldew et al., 1989; Bogin et al., 1994; Appenroth et al., 1997). However, little is known of the interaction of antitumor drugs with antioxi-

Departamento de Análises Clínicas, Toxicológicas e Bromatológicas, Faculdade de Ciências Farmacêuticas de Ribeirão Preto, Universidade de São Paulo, Av. do Café s/n, 14041-903 Ribeirão Preto, SP, Brasil. Send correspondence to L.M.G.A. Fax: +55-16-602-4163. E-mail:

lugreggi@fcfrp.usp.br dants (Gentile et al. 1998). In this study, we investigated the modulatory effects of vitamin C (VC) on the clastogenic action of DDP in Wistar rat bone marrow cells.

\section{MATERIAL AND METHODS}

\section{Animals and chemicals}

Six-week-old male Wistar rats (approximalety 100 g) were used. The animals were supplied by the Prefeitura do Campus Administrativo de Ribeirão Preto, USP. Chow and water were provided ad libitum.

DDP (Cisplatina ${ }^{\circledR}$, Platinil, Quiral Química do Brasil) was obtained from Hospital das Clínicas da Faculdade de Medicina de Ribeirão Preto, USP. VC (Redoxon $^{\circledR}$, Roche Chemicals and Pharmaceutics S.A.) was dissolved in distilled water immediately before use. VC (50, 100 or $200 \mathrm{mg} / \mathrm{kg}$ body weight; bw) was administered by gavage in a volume of $0.5 \mathrm{ml} / 100 \mathrm{~g} \mathrm{bw}, 10 \mathrm{~min}$ before DDP $(5 \mathrm{mg} / \mathrm{kg} \mathrm{bw}, i p)$. Experiments were performed for each dose of vitamin and for DDP alone. Control animals received an equal volume of vehicle solution. Six rats were used for each treatment. All animals were injected $i p$ with $2 \mathrm{mM}$ colchicine, $0.5 \mathrm{ml} / 100 \mathrm{~g}$ bw (Sigma Chemical Co.) $90 \mathrm{~min}$ before sacrifice. The rats were sacrificed $24 \mathrm{~h}$ after administration of DDP based on the retention of the drugs in tissues (Taylor, 1978).

\section{Scoring of slides}

Bone marrow preparations for the analysis of chromosomal aberrations in metaphase cells were obtained as described by Ford and Hamerton (1956). Only well-spread metaphases with $42 \pm 1$ chromosomes were analyzed. One hundred metaphases per animal were screened to determine the number of chromosomal aberrations per cell (CA/ cell) and the percentage of damaged cells (\%DC). The mitotic indices were obtained by counting the number of mitotic cells in 1000 cells per animal.

\section{Statistical analysis}

The differences in $\mathrm{CA} /$ cell, \%DC, and mitotic indices between treatments were compared statistically by analysis of variance and calculation of the F statistics with its respective $P$ value. When $P<0.05$, the mean values of each treatment were compared by the Tukey test in which the minimum significant difference for $\mathrm{P}$ was 0.05 . 


\section{RESULTS AND DISCUSSION}

Bone marrow cells are susceptible to oxidative damage and sensitive to clastogenic chemicals (Umegaki et al., 1997). As expected, rats treated with DDP (5 mg/kg bw) had a higher frequency of $\mathrm{CA} /$ cell and \%DC than the controls ( $\mathrm{P}<0.05$; Table I). The most frequent aberrations were chromatid breaks, followed by complex exchanges and chromosomal breaks. Treatment with VC decreased the CA/ cell and \%DC in DDP-treated rats (Figure 1). There were no significant differences in the mitotic indices between rats that received VC and/or DDP compared to the control group. Thus, DDP was not cytotoxic at the dose tested.

The clastogenic action of the above dose of DDP in somatic cells has already been reported for rabbits
(Morrison et al., 1981). Intraperitoneal doses of $0.13 \mathrm{mg}$ and $0.52 \mathrm{mg}$ of DDP/kg/day for 5 days in rats caused chromosomal aberrations in bone marrow cells (Levine et al., 1980). Kliesch and Adler (1987) observed an increase in the number of polychromatic erythrocytes with micronuclei in the bone marrow cells of mice treated with DDP. Chromosomal aberrations were also observed in bone marrow cells and differentiating spermatogonia of mice treated with $2.5 \mathrm{mg}$ of DDP/kg bw (Adler and El-Tarras, 1989).

$\mathrm{VC}$ has antioxidant and free radical scavenging activities, which suggests that this vitamin may modulate oxidative DNA damage in mammalian cells (Odin, 1997). This activity could reduce the incidence of chromosomal aberrations caused by free radicals generated by antitumor drugs such as doxorubicin and cyclophosphamide.

Table I - Mitotic indices, chromosomal aberrations and damaged bone marrow cells in the rats treated with vitamin C (VC) and/or cisplatin (DDP).

\begin{tabular}{|c|c|c|c|c|c|c|c|c|}
\hline \multirow[t]{2}{*}{ Treatment } & \multirow{2}{*}{$\begin{array}{c}\text { Dose } \\
(\mathrm{mg} / \mathrm{kg} \mathrm{bw})\end{array}$} & \multirow{2}{*}{$\begin{array}{l}\text { MI } \\
(\%)\end{array}$} & \multicolumn{4}{|c|}{ Total chromosomal aberrations } & \multicolumn{2}{|c|}{ Mean \pm SD } \\
\hline & & & $\mathrm{G}$ & $\mathrm{B}^{\prime}$ & B" & EX & $\mathrm{CA} /$ cell & $\% \mathrm{DC}$ \\
\hline Control & & $3.2^{\mathrm{a}}$ & 0 & 6 & 0 & 0 & $0.010 \pm 0.008^{a}$ & $1.00 \pm 0.80^{\mathrm{a}}$ \\
\hline \multirow[t]{3}{*}{$\mathrm{VC}$} & 50 & $3.3^{\mathrm{a}}$ & 0 & 3 & 1 & 0 & $0.006 \pm 0.004^{\mathrm{a}}$ & $0.60 \pm 0.40^{\mathrm{a}}$ \\
\hline & 100 & $3.0^{\mathrm{a}}$ & 1 & 4 & 0 & 1 & $0.010 \pm 0.008^{a}$ & $1.00 \pm 0.80^{\mathrm{a}}$ \\
\hline & 200 & $3.3^{\mathrm{a}}$ & 1 & 4 & 1 & 1 & $0.012 \pm 0.010^{\mathrm{a}}$ & $1.20 \pm 1.00^{\mathrm{a}}$ \\
\hline DDP & 5 & $2.4^{\mathrm{a}}$ & 10 & 164 & 14 & 23 & $0.352 \pm 0.049^{b}$ & $23.70 \pm 2.20^{\mathrm{b}}$ \\
\hline $\mathrm{DDP}+\mathrm{VC}$ & 50 & $3.0^{\mathrm{a}}$ & 6 & 41 & 8 & 2 & $0.095 \pm 0.018^{\mathrm{c}}$ & $8.70 \pm 2.00^{\mathrm{c}}$ \\
\hline $\mathrm{DDP}+\mathrm{VC}$ & 100 & $2.7^{\mathrm{a}}$ & 6 & 55 & 6 & 3 & $0.117 \pm 0.044^{\mathrm{c}}$ & $9.00 \pm 3.80^{c}$ \\
\hline $\mathrm{DDP}+\mathrm{VC}$ & 200 & $2.8^{\mathrm{a}}$ & 5 & 49 & 9 & 11 & $0.123 \pm 0.039^{c}$ & $9.20 \pm 2.40^{c}$ \\
\hline
\end{tabular}

$\mathrm{MI}=$ Mean mitotic indices; $\mathrm{G}=$ gaps; B' = chromatid break; B" = chromosomal break; EX = exchange complex; $\mathrm{CA}=$ chromosomal aberrations; $\mathrm{DC}=$ damaged cells; $\mathrm{SD}=$ standard deviation. Values in vertical columns followed by the same letter are not significantly different at the $5 \%$ level; values followed by a different letter are significantly different at the $5 \%$ level. $\mathrm{N}=6$ animals per group.

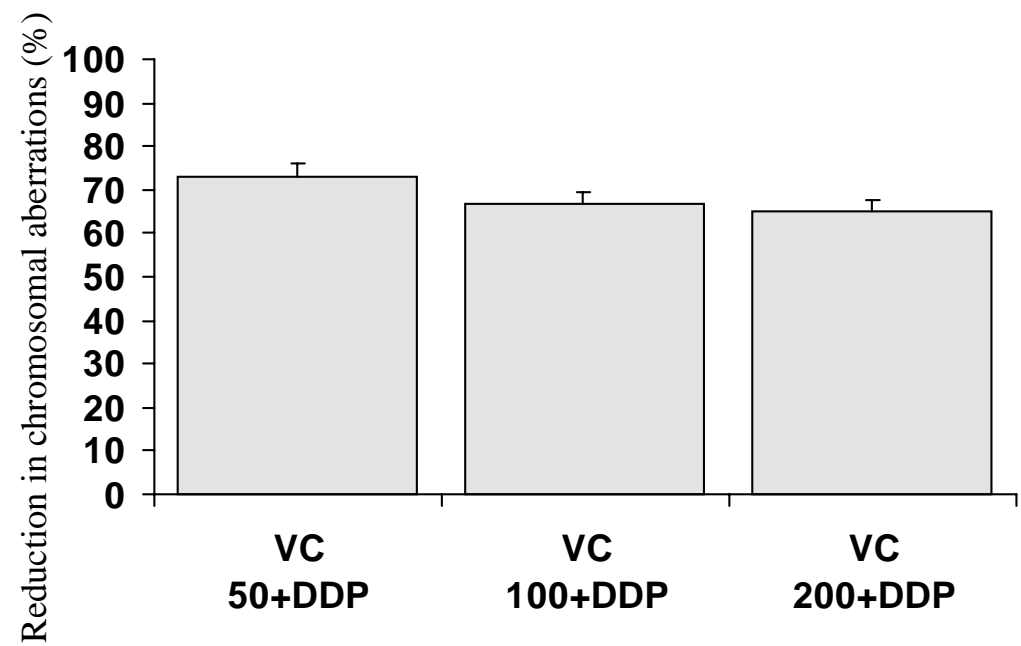

Figure 1 - Pretreatment with vitamin C (VC) reduces the number of cisplatin (DDP)-induced chromosomal aberrations/cell compared to rats treated with cisplatin alone. VC (50,100 and $200 \mathrm{mg} / \mathrm{kg} \mathrm{bw}$ ) was given by gavage $10 \mathrm{~min}$ before DDP (5 mg/ $\mathrm{kg}$ bw). Each column is the result from six rats. 
The three doses of VC used in this study inhibited DDP-induced chromosomal aberrations by about $70 \%$, indicating that $\mathrm{VC}$ protects against the clastogenic action of DDP. In mouse bone marrow cells treated with the mitomycin or cyclophosphamide, $\mathrm{VC}$ decreased the frequency of sister-chromatid exchanges induced by these drugs (Krishna et al., 1986). Similar protection was obtained in rat bone marrow cells treated with $\mathrm{VC}$ or olive oil in combination with the antitumoral drug doxorubicin (Antunes and Takahashi, 1998, and in press; Tavares et al., 1998). The reduction in chromosomal damage observed with VC suggests a selection for lethally injured cells or by the protecting effect of $\mathrm{VC}$.

The lack of a significant difference in the mitotic indices between the rats that received $\mathrm{VC}$ and/or DDP, compared to the controls showed that those compounds tested did not cause a cell cycle delay in bone marrow cells. This study suggests that antioxidant activity of VC was an important factor in counteracting the clastogenic effect of DDP. The inhibition of clastogenic activity may be related to the oxidative/reductive transmutation of $\mathrm{VC}$ involving the formation of a stable ascorbyl anion radical intermediate (Odin, 1997).

We conclude that $\mathrm{VC}$ reduces the clastogenic action of DDP in rat bone marrow cells. However, more detailed investigations in vivo are necessary before using vitamin supplementation in chemotherapy.

\section{ACKNOWLEDGMENTS}

Research and publication supported by FAPESP (Fundação de Amparo à Pesquisa do Estado de São Paulo, Brasil).

\section{RESUMO}

Neste estudo foi avaliado o efeito protetor da vitamina $\mathrm{C}(\mathrm{VC})$ sobre a ação clastogênica da cisplatina (DDP) em células da medula óssea de ratos. A DDP, um agente quimioterápico, foi injetada em ratos Wistar sozinha ou após o tratamento com a VC. Os animais foram tratados com VC $(50,100$ or $200 \mathrm{mg} / \mathrm{kg}$ de peso corporal) por gavagem $10 \mathrm{~min}$ antes da administração intraperitoneal de DDP ( $5 \mathrm{mg} / \mathrm{kg}$ de peso corporal). Os resultados obtidos mostraram que a VC foi efetiva na redução estatisticamente significativa da clastogenicidade da DDP em ratos Wistar (aproximadamente 70\%). O efeito antioxidante da $\mathrm{VC}$ foi proposto para explicar a modulação da ação clastogênica da DDP.

\section{REFERENCES}

Adler, I.-D. and El-Tarras, A. (1989). Clastogenic effects of cis-diamminedichloroplatinum. I. Induction of chromosomal aberrations in somatic and germinal cells of mice. Mutat. Res. 211: 131-137.

Antunes, L.M.G. and Takahashi, C.S. (1998). Effects of high doses of vitamins $\mathrm{C}$ and $\mathrm{E}$ against doxorubicin-induced chromosomal damage in Wistar rat bone marrow cells. Mutat. Res. 419: 137-143.

Antunes, L.M.G. and Takahashi, C.S. (1999). Olive oil protects against chromosomal aberrations induced by doxorubicin in Wistar rats. Genet. Mol. Biol. 22: 225-227.

Appenroth, D., Fröb, S., Kersten, L., Splinter, F.-K. and Winnefeld, K.
(1997). Protective effects of vitamin $\mathrm{E}$ and $\mathrm{C}$ on cisplatin nephrotoxicity in developing rats. Arch. Toxicol. 71: 677-683.

Baldew, G.S., van den Hamer, C.J.A., Los, G., Vermeulen, N.P.E., Goeij, J.J.M. and McVie, J.G. (1989). Selenium-induced protection against cis-diamminedichloroplatinum (II) nephrotoxicity in mice and rats. Cancer Res. 49: 3020-3023.

Baliga, R., Zhang, Z., Baliga, M., Ueda, N. and Shah, S.V. (1998). In vitro and in vivo evidence suggesting a role for iron in cisplatininduced nephrotoxicity. Kidney Int. 53: 394-401.

Bogin, E., Marom, M. and Levi, Y. (1994). Changes in serum, liver and kidneys of cisplatin-treated rats: effects of antioxidants. Eur. J. Chem. Clin. Biochem. 32: 843-851.

Crul, M., Schellens, J.H.M., Beijnen, J.H. and Maliepaard, M. (1997) Cisplatin resistance and DNA repair. Cancer Treat. Rev. 23: 341-366.

Ford, C.E. and Hamerton, J.L. (1956). A colchicine, hypotonic citrate, squash sequence for mammalian chromosomes. Stain Technol. 31: 247-251.

Gentile, J.M., Rahimi, S., Zwiesler, J., Gentile, G.J. and Ferguson, L.R. (1998). Effect of selected antimutagens on the genotoxicity of antitumor agents. Mutat. Res. 402: 289-298.

Keizer, H.G., Pinedo, H.M., Schuurhuis, G.J. and Joenje, H. (1990). Doxorubicin (adriamycin): a critical review of free radical-dependent mechanisms of cytotoxicity. Pharmacol. Ther. 47: 219-231.

Kliesch, U. and Adler, I.-D. (1987). Micronucleus test in bone marrow of mice treated with 1-nitropropane, 2-nitropropane and cisplatin. Mutat. Res. 192: 181-184.

Krishna, G., Nath, J. and Ong, T. (1986). Inhibition of cyclophosphamide and mitomycin $\mathrm{C}$-induced sister chromatid exchanges in mice by vitamin C. Cancer Res. 46: 2670-2674.

Krishnaswamy, G. and Dewey, W.C. (1993). Cisplatin induced cell killing and chromosomal aberrations in $\mathrm{CHO}$ cells treated during $\mathrm{G} 1$ or $\mathrm{S}$ phase. Mutat. Res. 293: 161-172.

Levine, B.S., Preache, M.M. and Pergament, E. (1980). Mutagenic potential of cis-dichlorodiammine platinum II in rodents. Toxicology 17: $57-65$

Masuda, H., Tanaka, T. and Takahama, U. (1994). Cisplatin generates superoxide anion by interaction with DNA in a cell-free system. Biochem. Biophys. Res. Commun. 203: 1175-1180.

Morrison, W.D., Huff, V., Colyer, S.P., DuFrain, R.J. and Littlefield, L.G. (1981). Cytogenetic effects of cis-platinum(II)diamminedichloride in vivo. Environ. Mutagen. 3: 265-274.

Odin, A.P. (1997). Vitamins as antimutagens: advantages and some possible mechanisms of antimutagenic action. Mutat. Res. 386: 39-67.

Ohe, T., Tsuda, S., Sakata, Y., Taniwaki, M., Misawa, S. and Abe, T. (1990). Cis-Diamminedichloroplatinum (II)-induced sister-chromatid exchanges and chromosome aberration formation in cultured human lymphocytes and their inhibition by sodium thiosulfate. Mutat. Res. 244: 279-285.

Osanto, S., Thijssen, J.C.P., Woldering, V.M., van Rijn, J.L.S., Natarajan, A.T. and Tates, A.D. (1991). Increased frequency of chromosomal damage in peripheral blood lymphocytes up to nine years following curative chemotherapy of patients with testicular carcinoma. Environ. Mol. Mutagen. 17: 71-78.

Rosenberg, B. (1985). Fundamental studies with cisplatin. Cancer 55: 2303 2315.

Tavares, D.C., Cecchi, A.O., Antunes, L.M.G. and Takahashi, C.S. (1998), Protective effects of the amino acid glutamine and of ascorbic acid against chromosomal damage induced by doxorubicin in mammalian cells. Teratog. Carcinog. Mutagen. 18: 153-161.

Taylor, D.M. (1978). The pharmacokinetics of Cis-diamminedichloroplatinum (II) in animals and man: relation to treatment scheduling. Biochimie 60: 949-956.

Umegaki, K., Uramoto, H. and Esashi, T. (1997). Lack of influence of a long-term high or low vitamin $\mathrm{E}$ diet on oxidative DNA damage in the bone marrow of mice. Int. J. Vitam. Nutr. Res. 67: 149-154.

Weijl, N.I., Cleton, F.J. and Osanto, S. (1997). Free radicals and antioxidants in chemotherapy-induced toxicity. Cancer Treat. Rev. 23: 209240.

(Received September 29, 1998) 
